\title{
Enhancing public participation in air pollution management from coal-fired power plant projects in Thailand
}

\author{
C. Chompunth \\ School of Social and Environmental Development, \\ National Institute of Development Administration, Thailand
}

\begin{abstract}
Air pollution is recognized as one of the most serious environmental problems in Thailand. One of the main sources of air pollution is coal-fired power plants. Either during the construction period or the operation period, the local communities surrounding the power plant are directly affected by air pollutants. This leads to conflicts among stakeholders. Accordingly, conflict over a power plant project is a significant problem in Thailand and needs to be solved immediately. To solve the problem, the participation in the planning and decision-making process of the power plant projects should be carried out in a proper manner. This study aimed at trying to close the gap between regulators and civil communities with respect to public participation in the Environmental Impact Assessment (EIA). A case study approach was selected for this study. Environmental laws and regulations relating to public participation practice in Thailand were reviewed and analyzed. The study revealed that current attempts at public participation in environmental planning and development in Thailand have not been effectively established. The Thai government's approach to handling environmental conflicts under Thai laws and mechanisms was topdown management and obviously ineffective. The Thai people demand greater participation in the decision-making processes concerning highly controversial issues of development activities, in particular the controlling of air pollution from power plants. They recognize that public participation should play a substantial role in environmental development projects and EIA.

Keywords: public participation, air pollution, EIA, coal-fired power plant, conflict.
\end{abstract}




\section{Introduction}

Moving from an agricultural base to more industrialization, Thailand now faces many environmental problems, particularly air pollution, resulting in health impacts consequences [1,2]. The industrial development of Thailand has contributed to air pollution problems in which it has influence on environmental conflicts and health problem of Thai people who lived in the development areas. The significant regions involved with the air pollution problems are such as Mae Moa Power Plant, Lumpang Province, Map Ta Phut Industrial Estate, Rayong Province, Laem Chabang Industrial Estate, Chonburi Province, and the downtown of various cities [1].

Coal-fired power plants are depicted as one of the top sources of air pollutants in Thailand since they release many pollutants and metals such as Sulfur dioxide $\left(\mathrm{SO}_{2}\right)$, Nitrogen oxides $\left(\mathrm{NO}_{\mathrm{x}}\right)$, Carbon dioxide $\left(\mathrm{CO}_{2}\right)$, mercury, acid gases, and particles that harm people's health [2]. Burning coal is also a leading cause of smog, acid rain, and toxic air pollution $[2,3]$.

Coal-fired power plants are leading source of $\mathrm{SO}_{2}$, which takes a major toll on public health, including by contributing to the formation of small acidic particulates that can penetrate into human lungs and be absorbed by the bloodstream. $\mathrm{SO}_{2}$ also causes acid rain, which damages crops, forests, and soils, and acidifies lakes and streams. $\mathrm{NO}_{\mathrm{x}}$ causes ground level ozone, or smog, which can burn lung tissue, exacerbate asthma, and make people more susceptible to chronic respiratory diseases [3].

Particulate matter, such as dust or fly ash, can cause chronic bronchitis, aggravated asthma, and premature death, as well as haze obstructing visibility. Power plants are also known as one of top source for an emission of mercury, a toxic heavy metal that causes neurological damage and heart problems, including lost IQ points, in babies and young children. Metals such as arsenic, chromium, and nickel can cause cancer. Acid gases cause lung damage and contribute to asthma, bronchitis and other chronic respiratory disease, especially in children and the elderly. Particles cause premature death and a wide range of lung and heart diseases [3].

The impacts from these air pollutants from the coal-fired power plant were critical and severe to people. Either the construction period or the operation period, the communities surrounding the power plant are directly impacted from these pollutants $[4,5]$. The cumulative impacts from the power plants were also critical to local residents. Although many emissions can be considerably reduced with readily available pollution controls; most coal-fired power plants in Thailand have not appropriately set up these technologies. Most of them are not well controlled. A previous coal-fired power plant, Mae Moa, in the North of Thailand has a bad reputation for its air pollutions. These rules will rely upon proven and widely available emissions control technologies to level that all power plants follow the same systems. Besides, in the past many coal-fired power plant projects had been implemented by the authorities without appropriate public participation $[3,6]$. This leads to conflicts among stakeholders. 


\subsection{Significance of the study}

Urgently, Thailand needs an effective approach to deal with air pollution problem; particularly, air pollutants from coal-fired power plants. However, Thailand has a very limited expert and specialists; this is then still an ongoing problem that still needs to be solved. Another problem is that the authorities usually stand by at central government centre. Presently, the government recognizes the importance of public participation to play a substantial role in the Environmental Impact Assessment (EIA) of coal-fired power plants in order to prevent their severe impact. Thai citizens also demand greater participation in the decision-making process concerning highly environmental and health impacts of development activities [5, 6], in particular of coal-fired power plants.

To deal with air pollution issue, Thai government is taking a coordinated approach to control air pollutions released from coal-fired power plants. Issuing several laws and regulations to limit these pollutants from power plants provides the industry with the certainty they need to make smart and cost-effective investments in control technology. It also encourages the public to involve in preserving and conserving the environment though many mechanisms, in particular legal framework. Thus, public participation in EIA process is expected to be an effective tool to solve these environment impacts and conflicts from the power plants.

This study aims to identify the problems of enhancing public participation in solving air pollutions in EIA process and to investigate strong and weak points of the EIA system in Thailand. A case study of the Khao Hin Son Coal-fired Power Plant Project was studied and analyzed. Finally, recommendations on how to enhance public participation in controlling pollutions form power plants in the Thai context are presented.

\section{Methodology}

\subsection{A case study approach}

In this study, qualitative approach was applied to examine the current state of EIA of power plant projects, both at the legal processes and adequacy of public participation in the EIA system. The case study approach is chosen as a key research strategy to explain and conduct an in-depth study of a public participation process in the EIA system in Thailand. In-depth interview and documental reviews were employed to collect data. Stakeholders who or played important roles in the public participation process were identified and interviewed. The secondary data were collected from relevant source including publications, substantive document on public participation, government publications, conference proceedings, research, books and journals. All relevant data were reviewed to build up knowledge and framework about the case study and public participation process. These processes aimed to provide background on the rationale for public participation and the Thai EIA system. 


\section{Results and discussion}

\subsection{Controversy of the case study: the Khao Hin Son coal-fired power plant}

The Khao Hin Son coal-fired power plant project is one of a large-scale project in the east of Thailand which having significant environmental problems, in particular air pollutions. The project is planned to be located in Chachoengsao province and is a co-investment between Thai firm Kaset Rungruang Peudphol and US Company CMS Co. Ltd. According to the Enhancement and Conservation of National Environmental Quality Act, B.E. 2535 (1992), power plant projects that have a production capacity exceeding 10 megawatts per day, must conduct and Environmental Impact Assessment (EIA) study and submit this EIA report before getting an approval from the Authority. Thus, the Khao Hin Son power plant project was required by law to conduct an EIA study. Accordingly, the Khao Hin Son coal-fired power plant is suitable to be examined how public participation process in managing environmental pollution control did not succeed since the project is having conflicts with a high level of controversy among stakeholders.

A coal-fired power plant is cited as one of the largest sources to particulate pollution, ozone, and global warming [1]. In this case, the affected villagers claimed that hazardous air pollutions emitted by coal-fired power plant could influence environmental quality and health on local, regional, and continental scales. One research participant claimed that "Their air pollutions blow across state lines into states thousands of miles away". The protesters said they did not want the power plant in their communities as they feared environmental impacts, particularly air and water pollution. One villager claimed that, "if the coal-fired power plant is established, it may result in the acid rain that will damage agriculture and cause mercury and heavy metal contamination in the air and food chains".

The villagers protesting against the construction of a coal-fired power plant in Chachoengsao called for a revised environmental impact assessment report of the project. They claimed that the existing report was conducted without appropriate public participation. The authority, the Office of Natural Resource and Environmental Policy and Planning (ONEP), approved the EIA study even though the company had not held public hearings or conducted a health impact assessment study as required by law, Section 67 of the 2007 constitution. One project opponent said that "The project's EIA has been done without appropriate public participation". A coordinator of a network monitoring the impact of the power plant also stated that "This means the EIA study does not cover all wellrounded information". However, one officer claimed that the office had considered the EIA report cautiously and the study complied with all legal requirements.

The protestors also believed that the power plant would cause massive environmental and social impacts, in particular air pollution, and agriculture sector. They also warned the government against repeating the mistake of Map Ta Phut, where the authority have been charged with violating Section 67 of the 
2007 Constitution requiring the agencies to consult an independent body before approval of projects deemed harmful to people's health and the environment. Importantly, the affected people did not trust the environmental monitoring and mitigation program of the project and still opposed the project. The local communities did not believe that the project's monitoring programmes could control any impacts to the environment from its operation. They believed that the government and the project owner were not honestly attempting to solve their problems and did not pay attention to their concerns. A network to monitor the impacts of the Khao Hin Son coal-fired power plant projects was then set up by the affected clusters. Thus, the Khao Hin Son power plant project was delayed and conflicts among stakeholders still exist. Similarly finding is found in the study of Tippett et al. [7]. The study found that mistrust has severed impacts to public participation in the EIA process. A lack of trust among stakeholders could hinder effective public participation and lead to conflict among stakeholders.

\subsection{Public participation in EIA in Thailand}

The EIA process is an essential component of environmental legislation in many countries including Thailand [8]. Historically, in Thailand, public participation is formally required only in the scoping stage of the EIA process but the current EIA practice requires public participation to be held in three main stages of the EIA process including screening, scoping, and EIA review. However, public participation as part of the site evaluation and selection processes, which are arguably sub-stages, is not compulsory and this potentially leads to conflict among stakeholders. This might be because project sitting has always been a key issue that created problems for project implementation in Thailand. Indeed, there were several factors that contributed to the conflicts, but the fact that people who lived near the proposed site did not know or have a chance to participate at the beginning stage of the project implementation, in particular the site selection process, is viewed as a key factor that caused the problems. Indeed, there are at least 5 steps in the Thai EIA Process including; screening, scoping, report preparation, EIA review, and monitoring. Public participation must be integrated in all steps $[5,8]$.

Although the EIA process was established more than 30 years in Thailand, it is still controversial; many developers regard EIA as an undesirable barrier, some seek to avoid the EIA process, and also some government administrators in charge of EIA view the process as a heavy burden. Moreover, political and financial support for EIA study is low in many developing countries, and environmental agencies are practically powerless compared with economic development agencies. Two key reasons for poor quality of EIA reports are lack of qualified environmental experts, and insufficient time and money [9], and Thailand is no exception in this regard.

Many scholars have commented on ineffective public participation process in Thailand on environmental issues and, particularly in the EIA process [4, 8, 9]. The draft EIA does not have to be released to the public, public comments are not asked for, and, critically, the government does not have to officially respond to public concerns. The EIA review is made by the authority in charge of the 
EIA approval only. Local expert panels and local administrative organization officers are not authorized to take part in the process. Usually after the EIA report is sent to the authority for review, the public could not get access to it [9]. Moreover, the EIA reviewers themselves are not experts in all areas, they work under pressures of time limits.

Clearly, public participation in the EIA process is crucial, particularly in Thailand. Weak public participation and unsatisfied communication produce many limitations, both legally and in practice, and result in limited knowledge and uneven distribution the project information to the local community. Finally, then the local communities distrust the EIA report and violent protests have been happened, like in this case.

\subsection{Law and regulations regarding public participation in Thailand}

Public participation has been constantly adopted and developed in Thailand since the government and the public recognised its significance and capability for solving environmental conflicts in the country [4]. Accordingly, the concept of public participation was officially introduced into Thai society through different laws and regulations, especially at national level. Thailand's core laws and regulations concerning the rights of citizens to participate in environmental management are such as: the Enhancement and Conservation of National Environmental Quality Act B.E. 2535 (1992); A Prime Minister's Public Hearing Order B.E. 2539 (1996); the Constitution of the Kingdom of Thailand B.E. 2540 (1997); The Official Information Act B.E. 2540 (1997); and the Regulation of the Office of the Prime Minister B.E. 2548 (2005). More recently, in 2007, the Constitution of the Kingdom of Thailand B.E. 2550 (2007) was declared. This Constitution explicitly responds to weaknesses of the old constitution and it is valuable to review this in order to determine its political and environmental context to correctly understand the present Thai system [10].

The Constitution 2007 encourages public participation in environmental management in Section 66 and 67. Particularly, Section 67 stipulated that any activities or projects that might cause seriously affect the quality of the environment and people's health could not be permitted, unless the impacts on the quality of the environment and the public's health have been studies and evaluated [11]. The 2007 Constitution also aims to reduce direct violence and environmental conflicts by enhancing public participation in decision-making process. However, Thai citizens are still being excluded from the participatory process, allowing violence to be reoccurrence in Thai society. This might because the Constitution has not had any impact on Thai social structure, political context, and conflict resolution approaches [5]. These barriers contribute to future conflicts. Thus, without appropriately analysis of these obstacles, it is difficult to understand the reoccurrence of environmental conflicts in Thailand.

With the intention of efficiently solving the air pollution problems in all areas nationwide, the 2007 Constitution and the Decentralisation Procedures for Local Administration Organisations Act B.E. 2542 (1999) highlight on decentralising the State powers and authorities toward the local communities for their 
independence and self-decisiveness. Accordingly, the Pollution Control Department (PCD) has established Thailand Air Pollution Centre of Excellence (TAPCE) on 14 January 2002 [12].

The purposes of TAPCE are to: educate and improve the human resources in air pollution, create a technical network of air pollution control and prevention; support the research and development on air pollution control technology and improve the human resources of the local and regional administration; competence and expertise in air pollution management. Thus the local authority and local people can operate and solve the air pollution problems in their own local communities [12].

With respect to the provisions of the Thai legal and regulations, it can be seen that Thailand's legislation encourages, confers and formalizes the concept of public participation in managing and protecting the natural resource and environment issues [10]. However, as evidenced from the Khao Hin Son Coalfired Power Plant Project. The Thai legal and regulation are unable to effectively handle the environmental problems and public participation is not appropriately set up. The failure of the Thai legislation might result from the lack of effective enforcement. This issue is also a practical problem of in the legal system in many countries, such as Turkey [13], and Kenya [14]. The studies showed that if laws and regulations relevant to public participation practices were inefficiently enforced, people would not participate appropriately and in the implementation of development projects. Environmental problems and conflicts would be more arisen.

\subsection{Lessons from the case study}

From the case study, it could be seen that the implementation of public participation in Thailand is now reaching an impasse. Many stakeholders, in particular the impacted communities, were reluctant to participate in many participatory forums provided by the government or the developer. Many public hearings or other activities were ignored by affected groups. The protestors did not accept them because they believed that these activities, particularly public hearing should have been processed before the decision-making process was completed. The Khao Hin Son coal-fired power plant is obviously demonstrated for the problem of lack of appropriate public participation in the right stage. Moreover, many mega development projects in Thailand cause conflict because the location of the proposed project had already been selected. In this case, land was already selected for proposed project without informing local people. There is no alternative for the public. Only the chosen location of the project is introduced and presented to the public during the hearing forum.

Public participation in the EIA process is important. Without the public being participated there is too much of a tendency to hide things, which can eventually lead to corruption and conflict among stakeholders [15]. Keeping the EIA study (or related documents) secret completely defeats the purpose of the EIA system. This can especially be a problem where the local communities are adversely impacted. Particularly in this case study, violent protests have been set up. 
Although public participation process is possible to express a government's willingness to share all perspective with stakeholders, in many cases in Thailand, public participation has been simply employed to ratify a decision that had already been made [5]. Furthermore, despite public participation arrangements, to accept these programs does not mean that the final outcomes of participation processes will be accepted and influenced the authority's final decision [4, 5].

A significant problem is that when opportunities to be involved are distorted and blocked by political structures and processes, affected people may employ direct action to increase their level of participation and power [16]. In Thailand, this direct action is often resulted in direct violence. The foregoing consideration and finding are fully supported by this case study. Similarly, Persson's [17] and Vantanen and Marttunen's [18] studies found that trust was closely related to openness and transparency. If trust is lacking, the public then are difficult to see the decision is transparent and led to protest and antagonism among stakeholders. When the stakeholders did not trust each other, conflict was likely to be more aggressive.

Importantly, in Thailand, the public has a limited role in the monitoring process, including either the constructing or operating stages. Indeed, the project proponents should be provided assurances over the running and maintenance of the power plant in order to increase the public's confidence that the project is of good quality with social, health and environmental soundness. Otherwise, it will be difficult to get support from the public. This is because the participation of local people and NGOs in monitoring the operational impacts of a project can lead to the early identification of environmental and social problems, and can increase public acceptance. Importantly, public participation must be continued throughout the project to prevent failure of the power plant's operation. In this study, one academic suggested that, "to deal with this issue, the developers should provide effective mechanism such as call centres or hotlines to respond to the public complaints and concerns. Thus, the developer could take prompt action to alleviate the problem".

\section{Conclusions}

Air pollution is one of the most serious environmental issues in Thailand. High levels of pollution endanger people's health, the quality of the environment, and provoke serious climatic changes on the global level. Therefore, this issue should be resolved immediately. For the Thai government, it is essential to take action to resolve and improve the situation with the air quality within the country urgently.

Enforcement of the EIA requirements is a compulsion. Having an appropriate review and approve a project's EIA report could help reduce the conflicts among stakeholders. However, mitigation of industrial air pollution, particularly from the coal-fired power plant, is not only the responsibility of the developers, but it also involves the diverse stakeholders including the government, experts, local communities and NGOs to participate in brainstorming of finding the desirable and accepted alternatives for air pollution abatement. Effective monitoring 
should be based on constant public participation. The government needs to ensure that the public could access to monitoring center information of the project. The authority and the developer need to get a variety of viewpoints from the affected citizens, particularly different ideas how to improve environmental quality, suggestions and comments. If this kind of two-way communication with society is ensured, it will help not only to increase the efficiency of monitoring problems, but also involve the public into active participation in environmental problems, air pollution management in particular.

Public participation is perceived as a wise strategy for a developing country, like Thailand. Public participation can prevent argument and conflict between the authority/project proponents and the affected communities and can reach a higher level of support for the decisions during all phases the project's planning, construction, and implementation. It could be sum that effective public participation can lead to a desirable and acceptable outcome, resolve conflicts, establish cooperation and collaboration among stakeholders, and improve the process and outcome of the environmental decision-making.

In Thailand, public participation is a key component of the government's administration. Public participation is granted in the 2007 Constitution, The Official Information Act, and many clauses in the environmental legislation. However, there are many limitations to these laws, both legally and in practice. Within these laws and regulations, the public right to information is often subject to the judgment of the government officials in charge. In this case, it was found that public participation of Thai citizens did not comply with a real concept of public participation; direct impacted people in the project did not have a chance to be informed and express their opinions from the very beginning and their concerns were not appropriately influence the decision.

It could be said that the public participation process was not yet properly established in the Thai context. Thus, there is an urgent need to create a sound approach and conditions of effective public participation which can assist in resolving environmental problems and conflicts. Effective enforcement of laws is essential. No matter how good they look on paper, if each stakeholder continues to go their own way without proper balances and participation, environmental conflicts would still occur and the quality of the environment could not be improved.

\section{References}

[1] Thanh, B. D. and Lefevre T. Assessing Health Benefits of Controlling Air Pollution from Power Generation: the Case of a Lignite-fired Power Plant in Thailand. Environmental Management, 27(2), pp. 303-17, 2001.

[2] Nuntavarn, V. V. and Vajanapoom, N., Health Impact from Air Pollution in Thailand: Current and Future Challenges, Environmental Health Perspective, 119(5), pp. 197-198, 2011.

[3] USEPA (U.S. Environmental Protection Agency), Health Effects of Air Pollution, Washington, DC. USA: EPA Web link: http://www.epa.gov loar/caa.Healthslides.pdf [Accessed: 29 January 2012]. 
[4] Chompunth, C. and S. Chomphan, Evaluating Public Participation Process in Development Projects in Thailand: A Case Study of the Khao Hin Son Power Plant Project, American Journal of Applied Science, 9(3), pp. 865$873,2012$.

[5] Ogunlana, S. O., T. Yotsinsak and S. Yisa, An Assessment of People's Satisfaction with the Public Hearing on the Yadana Natural Gas Pipeline Project, Environmental Monitoring and Assessment, 72(2), pp. 207-225, 2001.

[6] Chaisomphob, T., J. Sanguanmanasak and K. Swangjang, Role of Public Participation in Planning Power Plant Project in Thailand, Thammasat International 9(1), pp. 67-73, 2004.

[7] Tippett, J., B. Searle, C. Pahl-Wostl and Y. Rees, Social Learning in Public Participation in River Basin Management: Early Findings from Harmoni COP European Case Studies, Environmental Science and Policy, 8(3), pp. 287-299, 2005.

[8] Stampe, J.W., Lessons Learned from Environmental Impact Assessments: A Look at Two Widely Different Approaches - The USA and Thailand, The Journal of Transdisciplinary Environmental Studies, 8(1), pp. 1-7, 2009.

[9] Chesoh, S., Environmental Impact Assessment of Power Development Project: Lessons from Thailand Experiences, Asian Social Science, 7(9), pp. 119-123, 2011.

[10] Chompunth, C., Public Participation in Environmental Management in Constitutional and Legal Frameworks, American Journal of Applied Science, 10 (1), pp. 73-80, 2013.

[11] Office of the Council of State, Constitution of the Kingdom of Thailand, Government Gazette Press, Vol.114, part 55a, 2007.

[12] Office of Pollution Control Department (PCD), Thailand Air Pollution Center of Excellence: Introduction, Bangkok, Web link: http://aqnis.pcd.go.th/node/1843 [Accessed: 27 February 2012].

[13] Gunes, Y. and A. A. Coskun, Legal Structure of Public Participation in Environmental Issues in Turkey, Journal of Environmental Assessment Policy and Management, 7(3), pp. 543-568, 2005.

[14] Okello, N., L. Beevers, W. Douven and J. Leentvaar, The Doing and Undoing of Public Participation during Environmental Impact Assessments in Kenya, Impact Assessment and Project Appraisal, 27(3), pp. 217-226, 2009.

[15] Creighton, J. L., The Public Participation Handbook: Making Better Decisions Through Citizen Involvement, San Francisco, Jossey Bass, 2005.

[16] Harding, R., Environmental Decision-Making: the Role of Scientists, Engineers and the Public: The Role of Scientists Engineers and the Public, New South Wales, Federation Press, 1998.

[17] Persson, J., Theoretical Reflections on the Connection between Environmental Assessment Methods and Conflict, Environmental Impact Assessment Review, 26(7), pp. 605-613, 2006. 
[18] Vantanen, A. and M. Marttunen, Public Involvement in Multi-Objective Water Level Regulation Development Projects-Evaluating the Applicability of Public Involvement Methods, Environmental Impact Assessment Review, 25(3), pp. 281-304, 2005. 